All Papers

Osgoode Hall Law School of York University Osgoode Digital Commons

Research Papers, Working Papers, Conference

Papers

2012

\title{
Text Work as Identity Work for Legal Writers
}

Erika Abner

Shelley M. Kierstead

Osgoode Hall Law School of York University, skierstead@osgoode.yorku.ca

Follow this and additional works at: http://digitalcommons.osgoode.yorku.ca/all_papers

\section{Repository Citation}

Abner, Erika and Kierstead, Shelley M., "Text Work as Identity Work for Legal Writers" (2012). All Papers. Paper 18.

http://digitalcommons.osgoode.yorku.ca/all_papers/18

This Working Paper is brought to you for free and open access by the Research Papers, Working Papers, Conference Papers at Osgoode Digital

Commons. It has been accepted for inclusion in All Papers by an authorized administrator of Osgoode Digital Commons. 
Text Work as Identity Work for Legal Writers

Erika Abner and Shelley Kierstead ${ }^{1}$

\section{Introduction}

Lawyers, like their counterparts in other professions, develop a professional identity that is shaped by multiple influences - positive and negative, overt and hidden - both in law school and in practice. In this paper we aim to explore the phenomenon of text work/identity work for lawyers through an analysis of important legal writing literature. Text work/identity work has been described as the process of developing a professional identity, including an authoritative stance, in and through writing (Kamler \& Thomson, 2008). We have adopted at the outset the approach and standpoint presented by Kamler and Thomson in their analysis of dissertation advice books (2008). As described by Kamler and Thomson (2006), the authoritative stance for doctoral students engaged in knowledge production includes the ability to understand the relevant field or fields, make choices about literature(s), and adopt a critical yet respectful stance to the literature, all in circumstances where the student feels uncertain and overwhelmed. Fairclough (2003, p. 183) argues that professional (or social) identity is only truly adopted when one finds a way to manage between the 'distinctive elements ... in the mix.'

Kamler and Thomson (2008) examined a series of writing guides for doctoral students, grounding their study in the discourse analysis of the "self-help" literature. They found that many of these books presented a view of academic writing as a discrete set of technical skills that are context free and describe four recognizable patterns in the doctoral advice genre that created a transmission pedagogy. The patterns are: 1) an expert-novice relationship is produced and reproduced; 2 ) the process of writing is simplified to a series of linear steps; 3 ) writing advice is packaged as a set of over-generalized rules; and 4) the texts are emphatic and offer a paradox of reassurance and fear by asserting certainty and rejecting complexity.

\footnotetext{
${ }^{1}$ Erika Abner LLB LLM PhD, of the Ontario Bar, is an Educational Consultant. Shelley Kierstead LLB LLM PhD, of the Ontario Bar, is an Assistant Professor at Osgoode Hall Law School, York University.
} 
The more helpful books set out a different pattern, as they: 1) offer more than one best model with a set order of chapters; 2 ) demystify the process that experts use; 3) provide students with the possibility of understanding the socially produced complexities of writing wihout simply reducing them to individual deficiencies; and 4) make visible the discourses, the relations of power, and the pressure on academic work that govern the work of doctoral study but may be unknown to students. The authors of these books recognize the experience, knowledge and expertise of doctoral students and offer them an intelligent set of resources they can use to make decisions about their needs. They make explicit the crafting of a scholarly identity in and through text.

Knowledge production for law students and new lawyers is not the same as for doctoral students, and the goals of doctoral education are not the same as for legal education. However, we argue that lawyers must develop an authoritative stance as professionals and that they develop an authoritative stance and professional identity in the course of the preparation of documents in the service of clients. A considerable proportion of legal work is enacted in the many different types of documents that lawyers prepare: research memoranda, letters (opinion letter, advice letters, transmittal letters, demand letters, reporting letters), court documents (pleadings, briefs and facta, affidavits, orders, settlements, releases), by-laws and other corporate documents, and formal agreements such as contracts. These documents "make something happen" in the world: provoke a response, persuade a judge, transfer money or other property interest, create a relationship, dissolve a relationship, or tell a story. The lawyer's writing, whether public or private, becomes a representation of the lawyer in the world.

This representation in writing may be more or less grounded in an authoritative stance, which is an amalgam of the quality of analysis, attention to detail (including grammar), awareness of audience, attention to the client's problem, and ability to appropriately convey the nature and degree of risk (Kierstead \& Abner, 2010). As well, the representation of the lawyer in the world may be reflected in the document tone. The tone can be aggressive, conciliatory, amusing, or timid; the tone of a particular document may or may not be the result of conscious choices at the service of the client. 
We aim to explore the extent to which legal writing texts for law students and practitioners describe the impact of writing on professional identity. We examine the extent to which legal writing texts, intended to guide law students and lawyers toward competent legal writing, address the question of whether and how lawyers' documents and professional identities are shaped together, either explicitly or implicitly. The work is primarily descriptive aimed at identifying thematic messages located within the texts. The thematic messages, in turn, are linked to the broader literature about teaching and learning professional identity, community of practice, and the manner in which the legal community "talks to itself". Our inquiry includes learning to write in law school and learning to write in practice.

Law schools may or may not be required to offer a writing program to students. In the US, the American Bar Association [ABA] requires accredited law schools to offer a legal research and writing program in first year. ${ }^{2}$ In the past twenty years, there has been a near-explosion of publishing textbooks designed for first year research and writing courses in the United States (Mersky, 2007). In Canada, the Federation of Law Societies of Canada released its report titled Task Force on the Canadian Common Law Degree (Law Societies, 2009). Within its report, the Task Force proposed "a national requirement expressed in terms of competencies in basic skills, awareness of ethical values and core legal knowledge that law students can reasonably be expected to have acquired during the academic component of their education." (Law Societies, 2009, p. 809) These competencies include skills in oral and written communication. The report's adoption by provincial Law Societies will no doubt impact law schools' curriculum decisions.

Virtually all Canadian law schools already offer some training in research and writing. At the core, these law school courses provide basic training in research and memo writing and might also offer some instruction and experience in other types of legal writing as described above. The books used within these courses typically familiarize students with the concept of stare decisis, the essence of the research process, legal analysis techniques, and differences between predictive and persuasive writing. They often provide particular formats for arranging

\footnotetext{
${ }^{2}$ http://www.americanbar.org/groups/legal_education/resources/standards.html 2010-2011 ABA Standards for Approval of Law Schools Standard 302 (a).
} 
written legal analysis (example, IRAC - "Issue, Rule, Application, Conclusion"), and most typically address the writing of an office memorandum. Coverage of other types of legal documents varies. Most law students, however, have limited exposure to the array of documents that many lawyers would write in the course of their day to day practice.

Lawyers learn to write primarily in practice and the types of documents they produce depends on the type of practice in which they are engaged. Lawyers employed in large multiservices firms may be offered specific internal programs in legal writing; continuing legal education providers also provide programs at varying levels of specificity. Most lawyers learn to write on-the-job through observation, experience, and with luck, feedback on their products.

Over the past twenty years (or so) a considerable number of books on writing in practice have been published. Some offer general advice about legal writing (Wydick, 1998); others are specific to formal drafting (Adams, 2004; Elderkin \& Doi, 1998), advocacy (Garner, 2004), or a variety of different documents (Schiess, 2003). The majority have been written by practicing lawyers and are based on the practitioner-author's experience, with some references to case law where appropriate or to judicial preferences in advocacy writing. Specialized journals such as Scribes and columns in highly regarded practitioner journals such as Practical Lawyer and Practical Litigator also address aspects of legal writing.

In Part I, we begin with a discussion of the literature on the legal "voice", which is linked to the current discussion on the three apprenticeships in professions learning. We then briefly review debates about the "ethical lawyer" and legal professionalism to conclude that, regardless of the model of professionalism adopted, the development of an authoritative stance in relation to problem solving remains an essential aspect of professional identity. In Part II, we describe the rationale and methodology for the discourse analysis that we have undertaken. Part III discusses themes revealed through the document analysis, and Part IV discusses how the findings relate to the influence of texts on the development of professional identity. 


\section{Part I: Voice}

The discussion of identity is often linked to the idea of "voice". One sometimes encounters commentary about the alienation lawyers feel when they are disconnected from the writing they are doing. One author states: "We can rightfully wonder about the psychological effect on lawyers of producing this artificial language all day, every day." (Litowitz, 1998, p. 710) Our inquiry into text work as identity work addresses theories of voice in legal writing. Rideout has reviewed accounts of how the metaphor of "voice" has been characterized (J. C. Rideout, 2009; J.C. Rideout \& Ramsfield, 2010). He describes characterizations of "the voice of the law" - one that is impersonal, general, formal, and impersonal. It is this form of voice that Rideout suggests is most closely aligned with legal writing courses. Formal, impersonal writing was heavily criticized through the 1980s and 1990s by expressivist writers such as Peter Elbow (1998) who worked to inject "personal" or "authentic" voice into writing. Rideout suggests a different view of voice, premised on the idea that legal writing represents the writer - with all of her or his experience - interacting with legal discourse conventions, and specifically, with particular speech genres (for example, a legal factum or brief prepared for a court). Within this process, one's professional identity is represented by his or her written representation, and there are different degrees of particular authorial presence contained within different documents. For example, while a first year predictive legal memo would contain little authorial presence and would aim primarily at engaging with the relevant legal discourse, a dissenting judicial opinion engages with legal discourse, but clearly illustrates the unique authorial presence of the dissenting judge.

There are differing theories about what voice and identity within written work mean; the question of how the writing process shapes the development of these concepts is also ripe for theoretical analysis. One recent study has begun to look at the development of first students' construction of professional identity as illustrated through their efforts to write an opinion letter for a writing course (Maclean, 2010). MacLean describes the challenges that students experience when attempting to accommodate different aspects of "voice" (advice, legal strategy, legal interpretation) within a written document. MacLean concludes that "[e]xplicit attention to identity as part of the teaching of legal writing may have immediate 
benefits for the writing skill and for the general well-being of legal practitioners." (2010, p. 192)

Rideout and Ramsfield also call for further research into legal writing and identity ... "partly because ... it is through the construction of the discoursal self of the writer that we as legal writing professors can understand more practically what it means for legal writers to socialize into legal discourse" (2010, p. 17). In our own research into expert performance, we found some evidence that senior lawyers connect both the writing process and product with their sense of professional identity (Kierstead \& Abner, 2010).

\section{Professional Identity}

The development of a professional identity, described in the Carnegie Report [Report] (Sullivan, Colby, Wegner, Bond, \& Schulman, 2007) as the apprenticeship of identity and purpose - in law school and beyond has recently attracted scrutiny in both the academy and profession (Bebeau, 2008; Colby \& Sullivan, 2008; Floyd, 2007; Hamilton, 2008; Hamilton \& Brabbit, 2007). The extensive Preparation of the Professions research undertaking ${ }^{3}$ has developed and examined the concept of the three apprenticeships of learning across five professions: medicine, nursing, law, engineering, clergy, and the doctorate. As the researchers describe the three apprenticeships:

(1) Intellectual training to learn the academic knowledge base and the capacity to think in ways that are important to the profession;

(2) A skill-based apprenticeship of practice: the craft know-how that marks expert practitioners of the domain; and

(3) An apprenticeship to the ethical standards, social roles, and responsibilities of the profession, grounded in the profession's fundamental purposes. (Colby \& Sullivan, 2008, p. 409)

For each profession, the researchers examined how each apprenticeship was taught and learned, and which apprenticeship was most prominent. In certain professions, including law, this third apprenticeship is overshadowed by the intense focus on the first apprenticeship of the intellectual: "thinking like a lawyer". They concluded that, in legal education, the first

\footnotetext{
${ }^{3}$ http://www.carnegiefoundation.org/previous-work/professional-graduate-education.
} 
apprenticeship of cognition has overshadowed the other apprenticeships and that the third apprenticeship of professional identity has been significantly marginalized (Colby \& Sullivan, 2008; Sullivan, et al., 2007). To support student development, all three apprenticeships should remain "in dialogue throughout the process of learning the law." (Sullivan, et al., 2007, p. 142)

The Report notes the importance of the pedagogy of legal writing and its capacity to unite the three apprenticeships through the creation of documents, small group learning, feedback on written work, and capacity to raise issues of simulated practice. While the Report does not directly address text work/identity work as a concept, there are some allusions to the power of learning through writing:

Many students with whom we spoke noted the ways in which their writing courses accelerated their progress in legal reasoning in their doctrinal courses, especially seminars beyond the first year; some wanted more such linkage. In these examples, legal writing is already coming to play an important role in helping students to cement basic patterns of legal thinking; it also serves as a bridge between the learning of legal thinking and the mastery of the skills demanded in order to practice law. (Sullivan, et al., 2007, p. 108)

A robust program to develop professional identity in law school should focus at least in part on the development of an authoritative authorial voice that will survive and flourish in practice - particularly in a profession where the enduring values may be "mis-aligned" with its education (Colby \& Sullivan, 2008). While law schools provide formative experiences, current research in other professions leads to the conclusion that writing in school and writing in practice are profoundly different.

Several researchers have addressed these differences between writing at work and writing in school, described generally as differences in complexity, multifunctionality and implications of power relations (Dias, Freedman, Medway, \& Paré, 1999). These studies examined the transitions for engineers (Winsor, 2001), social workers (LeMaistre \& Paré, 2004), architects (Dias, et al., 1999) and government workers (Freedman \& Adam, 1996). These studies challenge the notion that teaching writing to law students can be an authentic activity 
so that students can "hit the ground running" as they enter practice. Instead the academy offers a simplified form of power relations [student-professor] and limited, if any, references to the complexity and multi-functionality of legal documents. As noted previously, students learn to write like lawyers within the community of practice through a complex process of observation, imitation, assistance, and mistakes. In particular, they learn to manage the tensions (Maclean, 2010) and to understand the complexity, multi-functionality, and power relations required to prepare documents (Kierstead \& Abner, 2010).

Many questions exist in relation to what it means to be a "good" legal professional, and how personal and professional attributes blend to create one's legal identity. These questions are intricately related to how individuals interact within the community of practice with which they are associated. The manner in which these issues are addressed influences the way that particular individuals approach the writing task, and the development of an authoritative stance within that task. Based on our previous research with senior lawyers, demonstrating an authoritative stance within a written document involves, among other things, the ability to understand and use authority properly, the ability to understand the "bigger picture" - that is, the context within which the written product is being created, and the opportunity to write, rewrite, and obtain feedback. For most of the lawyers, acquiring strong writing skills was very much a part of legal identity - as one participant noted "... [T] hat is your image, and it's the image you project either to the profession, the world or whatever. And it's either one of crispness or intellectual sloppiness." (Kierstead \& Abner, 2010, p. 389)

\section{The "Ethical Lawyer" Debate}

Part of the discussion about what it means to be a "good" legal professional is linked to debates about the ethical aspects of the lawyer's role. Increasingly, the model of lawyering that sees the lawyer as a "hired gun" whose interests are defined only by their client's interest is being challenged by theories that reject the idea that practical and moral consequences are the sole responsibility of the client (Atkinson, 1995). While the concept of "zealous advocacy" still figures prominently in codes of professional conduct, it is being tempered with language such as "resolutely" and "honourably," which depicts the lawyer as more than simply a neutral 
partisan. ${ }^{4}$ Some authors have suggested that a much more significant departure from the neutral partisan stance is required, and that "[l]egal ethics is a life-long challenge in which lawyers must be encouraged to go beyond simply learning the rules and how to apply them; they should constantly interrogate themselves and their colleagues about the moral status of their work and practices." (Hutchinson, 1998) Others go further, suggesting that that client choice should be guided by one's own moral compass: "You should feel guilty, and we should disapprove of you, if you go ahead and argue a cause you think will do more harm than good." (Kennedy, 1987, p. 158) It is safe, we suggest, to conclude that the evolving characterization of the lawyer as an "ethical" professional is one that involves a fusion of personal and professional attributes. Trevor Farrow suggests that we are engaging in

a new discourse for lawyers and the legal profession that is seeking to become personally, politically, ethically, economically, and professionally sustainable. It is a discourse that makes meaningful space for a lawyer's own principles, interests, and life preferences by balancing them with other important interestsincluding, but not dominated by, those of the Client ...(2008, p. 55)

Our purpose in this work is not to delve into the intricacies of the components of ethical lawyering. However, we do agree with Farrow that the traditional isolation of personal from professional does not reflect the most commonly accepted perspective on ethical lawyering. Rather, the paper proceeds on the premise that personal values and experiences are relevant to the development of a strong professional identity as represented through written legal products. It is not necessary to identify precisely the extent to which personal characteristics impact on the development of professional identity - this may well vary from person to person. Our point is simply that the connection between the two does exist, and is reflected in the lawyer's written product.

\footnotetext{
${ }^{4}$ Rule 4.01 (1) of Ontario's Rules of Professional Conduct provides: When acting as an advocate, a lawyer shall represent the client resolutely and honourably within the limits of the law while treating the tribunal with candour, fairness, courtesy, and respect. Law Society of Upper Canada, Rules of Professional Conduct (Adopted by Convocation June 22, 2000).
} 


\section{Teaching Professional Identity}

Debates also abound in relation to the most appropriate way to teach professionalism, and in particular, ethical professionalism (Longan, 2008; Walker, 2008). Some law schools have adopted resolutions requiring the inclusion of ethical issues within each course; others have adopted stand-alone courses focused exclusively on ethical lawyering (Farrow, 2008).Additionally, clinical experiences are viewed as an ideal manner by which to have students gain an understanding of professional responsibilities and ethical issues that arise in the course of a lawyer's standard practice (McCormack, 2008; Sullivan, et al., 2007). An uncharted area within academic literature is the extent to which legal writing texts can provide guidance to students (and perhaps to teachers) about ways in which the legal writing process can assist lawyers-in-training and lawyers to develop professional identities that are expressed through legal writing that adopts an authoritative stance in relation to the subject matter of the writing task.

\section{Part II: Methodology}

The current work employs discourse analysis. This analytic approach is appropriate for a review of documents with a view to considering the connection of words used within documents (often media accounts, but not necessarily so) to the establishment of central themes (Nueuendorf, 2002, p. 5). These themes, in turn, can be used to better understand underlying discourses that motivate particular acts (Nueuendorf, 2002, p. 6). In particular, constructivist discourse studies "aim at understanding the intricate way in which discourses lead to the creation and reification of certain phenomena" (Phillips \& Hardy, 2002, p. 416). In our analysis, we are particularly concerned with the phenomena of the profession talking to itself through legal writing texts.

Our analysis focused on two types of legal writing texts: (1) those written with law students as the intended audience; and (2) those written with practicing lawyers as the intended audience. We made a selection of texts written for law students in Canada and the United States that were widely available to students within law libraries, and that are commonly listed in legal writing course syllabi. The five practitioner texts were chosen on the 
basis of popularity as represented by number of sales through on-line retailers, references by knowledgeable legal writers, and personal preference.

The analytic procedure adopted for the current work began by dividing the sample of texts into the two groups articulated above. We then read the entire books, establishing a set of words and phrases used by the authors in relation to our research questions:

1. Do the texts include specific or implied references to a personal or professional identity/voice?

2. How do the texts position the legal writer within the community of practice?

3. How do the texts position the relationship of teacher and learner?

After reviewing the words and phrases generated within a pilot coding exercise, we were able to establish catagories of meaning. These categories were, we found, identifiable with emergent themes: how the authors represented legal writers, (positive, negative, neutral); how the authors represented the writing tasks (goals as a writer, impediments to writing, conflating legal writing with other writing) and whether the authors made any reference to legal identity or legal voice. These emergent codes were then applied to a selection of specific works to develop representative quotes. The quotes were analyzed both within and between each set of texts with the objective of discovering both trends and contrasting approaches. At least $10 \%$ of each text was coded by both coders in order to check for inter-coder reliability. We report on the emergent themes in Part III of this work, using illustrative quotations from the texts. The quotes also illustrate attention to negative cases - that is, those that did not follow certain identifiable trends.

\section{Sample First Year Texts}

Sirico, L. J. and Schulz, Nancy L. (2001). Persuasive Writing for Lawyers and the Legal Profession. Lexis Publishing.

McCallum, M. E., Kunz, C. L., \& Schmedemann, D. A. (2003). Synthesis: legal reading, reasoning and writing in Canada: $\mathrm{CCH}$ Canadian, Ltd. 
Neumann, R. K. (2003). Legal reasoning and legal writing: Structure, strategy, and style: Citic Pubulishing House.

Oates, L. C., Enquist, A., \& Kunsch, K. (1995). The legal writing handbook: research, analysis, and writing: Aspen Publishers.

\section{Sample Practitioner Books}

Armstrong, S., \& Terrell, T. (2003). Thinking Like a Writer: A Lawyer's Guide to Effective Writing and Editing (Second ed.). New York: Practising Law Institute.

Garner, B. (2001). Legal Writing in Plain English. Chicago: The University of Chicago Press.

Stark, S. D. (2000). Writing to win: the legal writer: Broadway Books, New York.

Wydick, R. (1998). Plain English for Lawyers (4th ed.). Durham: Carolina Academic Press.

We recognize that these texts represent a small sample, and that, as such, the transferability of findings may be limited. However, "even studies with small samples may help to identify theoretically provocative ideas that merit further exploration." (Russell \& Gregory, 2003) From the findings below, we hope to introduce a number of theoretically provocative ideas.

Unlike other methods of qualitative research, discourse analysis does not always permit certain strategies to ensure trustworthiness, such as triangulation, member checking, or participant involvement. We did employ the method of searching for disconfirming evidence within the texts; that is, to examine the texts closely for all instances within the coding framework and reporting both negative and positive statements. As will be seen in the findings, this approach led to a structure that supports quite different views of the professional identity learned through writing. 


\section{Part III: Findings}

\section{VOICE: First Year Texts}

Our research suggests that some first year legal writing texts recognize aspects of the voice issue. Largely, the recognition comes in the form of professional credibility and image projection:

- Putting yourself in the message can often add to your credibility ... [This] may have more applicability in letters to clients or other [non-court related] types of legal writing [Sirico \& Schulz]

- In addition to selling competence, you are selling an image. [Enquist, Oates, Kunsch]

Additionally, however, there is reference to the recursive process of writing and development of an authoritative stance:

- Learning how to write like a lawyer is the beginning of learning how to make professional decisions. [Neumann]

Further, one of the texts reviewed seemed directly aligned with Rideout's description of the writer as one whose life experience interacts with legal discourse conventions:

- It may seem that focusing on the reader means that your voice, as a writer, is muffled. .. Nonetheless, it is your analysis ... Your analysis inevitably will reflect your values, your creative ways of thinking about problems, and your choice of words [MacCallum]

Though reference to voice is present within the texts, the representation of voice varies from one text to the next. 


\section{VOICE: Practitioner Texts}

\section{Specific and Implied References to Voice}

We found relatively few specific references to voice in the practitioner texts.

- Ultimately, you'll have to answer a question that your parents started helping you answer before you understood a single word: what kind of person am I? And every time you write, you'll be answering some related questions: what kind of person am I - on paper? What do I sound like? If you want to write well, you'll have to resist sounding like a machine. Or a foreign philosopher in translation. You'll have to learn to sound like yourself. It's even possible that you'll find yourself by learning to write well. [Garner]

- Even their personal experience must be banished from the written page - a clear invitation to resort to the "institutional passive" voice, which further separates writer from reader. "It could be argued" write most lawyers, never pointing out that there is an "I" doing the arguing. As a consequence, very little legal writing reveals much about the author. [Stark]

- In a brief, therefore, your goal is to become the judge's alter ago - not your opponent's most virulent enemy or your client's most vociferous supporter. [Armstrong]

- What matters most, in the end, is how you apply sound practices in your writing. You'll have to use good judgment. No blackletter rule can substitute for that. [Garner]

The second theme that emerged from our coding process was that of characterizing the way that texts position the legal writer within the community of practice. Elements determined to fall within this thematic scope were: how authors characterize the goals of legal writers; how they des cribe the student/young lawyer's emerging role within the legal profession, and whether/how they describe the increasing complexity, multifunctionality and power issues that go hand in hand with the school to work transitions. There are, of course, no bright lines demarking these categories - instead, there are several areas of overlap. 


\section{Goals as a Writer: First Year Texts}

Virtually all of the first year texts' characterization of the goals of writers are tied to an overall obligation to provide client service:

- The better you serve the needs and expectations of your audience, the better you serve your client. [MacCallum]

Some delve into the more nuanced aspects of client service, such as persuasive advocacy:

- When you are communicating in writing, it is important to know your job. Stick to what you need to say to accomplish your goal. ... Make the arguments that are likely to sway the judge in your favor, and only those arguments [Sirico \& Schulz]

Others introduce the additional idea of protecting oneself - presumably from liability:

- You are including an issue statement because you want the client to know that you were listening and because you want to protect yourself [Oates, Enquist, Kunsch] 


\section{Goals as a Writer: Practitioner Texts}

- Legal writers face two competing obligations. They must do full justice to the complexity of their subject matter, no matter how torturous or ambiguous it is. Then they must transform all that complexity into a prose so lucid, so crisp and direct, that it will satisfy readers who demand absolute clarity even when - in fact, especially when-the subject is most obscure. [Armstrong]

- But you'll have to be willing to embrace simplicity- while always resisting oversimplification. Of the hurdles we've discussed, this will be the most difficult. It will require mental candlepower and maturity. [Garner]

\section{Emerging Role: First Year Texts}

First year texts address the emerging role that law students will play as they move closer to legal practice. Characterizations include: reference to the reality of words as a lawyer's tool; relationship between the lawyer's role and the practice jurisdiction's Rules of Professional Conduct; and legal writing as story-telling on behalf of a client:

- Contrary to the aphorism, a lawyer's stock in trade is neither time nor advice. It is words: writing them, speaking them and interpreting them ... Words are the principle tools of lawyers and judges ... whether we like it or not [Neumann]

- Your role is determined, at least in part, by your state's Rules of Professional Conduct [Oates, Enquist, Kunsch]

- The fact statement tells the reader the client's story. If the lawyer has talked only to the client, the story is told through the client's eyes. If the lawyer has investigated the facts, the facts include information obtained from other sources [MacCallum]

Similarly, references to the transition from school to work, while appearing infrequently, tend to paint a positive challenge for young writers: 
- When you write - and in every other part of the practice of law - you will be confronted continually with a range of choices about what to do. And your success as a lawyer will depend on your ability to understand the choices available and to select wisely among them. Now is a good time to start learning how ... [Neumann]

\section{Emerging Role: Practitioner Texts}

The representations of legal writers could be placed on a continuum from positive to negative. At the positive end, legal writers were represented as engaged in the difficult activity of communicating dense complex material in such a way as to satisfy readers who demand clarity. As Armstrong describes legal writers: “...they face a tougher task than most writers ever confront: writing clearly and persuasively about complicated matters when the stakes are high and the readers are impatient, often irascible, and sometimes hostile." (Armstrong \& Terrell, 2003, p. vii)

At the other end of the continuum are the authors who describe legal writers as limited or even duplicitious: “Perhaps most damaging, however, is lawyers' frequent use of language as a deception." (Stark, 2000, p. 265) 


\section{Positive Representations}

- Instead, they seek advice because they face a tougher task than most writers ever confront: writing clearly and persuasively about complicated matters when the stakes are high and the readers are impatient, often irascible, and sometimes hostile. [Armstrong]

- First, in law school, you discover that something non-lawyers assume to be relatively simple-"the law" -is in fact far from it. To learn to think like a lawyer, you have to become rigorously logical, to grasp subtle distinctions, to be fanatical about precision and thoroughness. Above all, you have to tolerate complexity, perhaps even love it. [Armstrong]

\section{Negative Representations}

- To write like a lawyer, at least in traditional terms, is to choose a perspective that cheapens language and forces us to relate to a narrow world of rules, not people. [Stark]

- The use of precedent also leads to repetitive writing. A system founded on precedent requires a form of logic in which rules are restated repeatedly and altered only incrementally. Because what changes most from case to case is the facts, not the laws or precedents, judicial opinions keep their discussion of facts to a minimum. In imitation, lawyers also write about rules, not facts. [Stark]

- We learn our trade by studying reams of linguistic dreck - jargon-filled, pretentious, flatulent legal tomes that seem designed to dim any flair for language. When on the job, we read poor prose almost exclusively. It's wordy and high-flown - oddly antique-sounding. And a little part of you may well come to believe that you must sound that way to be truly lawyerlike. [Garner] 


\section{Relationship Between Teacher and Learner: First Year Texts}

Within our analysis, we looked at how the texts address the relationship between teacher and learner from two angles - first, the extent to which legal writing is conflated with the overall writing process, and second, the way that impediments to good legal writing are characterized.

\section{Conflating Legal Writing: First Year Texts}

One of our "discoveries" not reflected in the quotes presented within this work is the fact that there are many lists and simplified frameworks for various writing texts. These appear within both the first year and practitioner texts. Additionally, there is much linear language and positioning of the teacher as expert (and, accordingly, the student as novice). There is a fairly limited explicit reference to the fact that good legal writing is hard work. Conflating good legal writing with good general writing tends to negate this reality:

- The demands of lawyerly writing come as a shock to many law students ... [I]f you've had trouble with your writing in the past, now is the time to learn to do it right [Neumann]

- Legal writers (indeed, all writers who wish to be understood) should keep in mind basic principles of communication [MacCallum]

- Clear, concrete language and well-supported, well organized arguments will work well with any audience. [Sirico \& Schulz]

It should be noted, however, that there is some reference to the recursive relationship between thinking and writing, which suggests a less linear, and more complex process: 
- The writing process and the thinking process are inseparable, each stimulating and advancing the other. [Neumann]

\section{Conflating Legal Writing: Practitioner Texts}

- Second, in my courses, l've tried to include examples and maxims from the worlds of journalism, advertising, and fiction writing. Anyone who can write a good ad can probably write a good legal argument, just as any good journalist probably knows how to compose a good statement of facts in an appellate brief. My view is that good writing tends to be pretty much the same everywhere. [Stark]

- The premise of this book is that good legal writing should not differ, without good reason, from ordinary well-written English. [Wydick]

\section{Impediments to Good Legal Writing: First Year Texts}

Again, in assessing the impediments to good legal writing, first year texts tend to suggest a fairly streamlined path from writer error to poor writing. The path can stem from writers block and tight deadlines. A more reflective stance is also, however, presented at certain points: 
- Writer's block happens to everybody from time to time ...[Neumann]

- In law, you are writing against a deadline ... [Neumann]

- In their eagerness to get their thoughts onto the page, even experienced writers .... sometimes forget precisely what their goal is when they sit down to write a persuasive document [Sirico \& Schulz]

\section{Impediments to Good Legal Writing: Practitioner Texts}

Positive descriptions of impediments acknowledge the difficulty and complexity of legal writing. The negative descriptions include references to greed (it suits lawyers' financial interests to write poorly), fear (better to follow outmoded language precedents than to risk reversal), history (we've always done written this way), and the nature of law practice (adopt the senior practitioners' and even judges' writing styles without question or challenge). These texts offer a bleak picture of the community of legal writers.

Time

- You'll undoubtedly find that time pressures make writing and revising difficult. [Garner]

Greed

- There's something about the culture of the law that produces terrible writers - which is why most law students say, accurately, that they graduate as less accomplished writers than they were when they arrived at law school. In part, lawyers write badly because that promotes their economic interests. [Stark]

Epistemology

- First, lawyers see a world dominated by precedent. It is one of the law's timeless truths that everything is merely an extension or alteration of what has appeared before. Thus, in their briefs and legal opinions, lawyers constantly explain things in terms of the past; they reason that they are doing nothing new and only following existing precedent. [Stark] 


\section{Part IV: Discussion}

The legal writing literature is consistent with the literature on doctoral students in its limited focus on the identity work inherent in learning to write with authority under conditions of uncertainty; the social practice of writing receives relatively little attention.

Within the context of the three apprenticeships described earlier in this work, first year writing texts provide quite strong coverage of the first apprenticeship - learning to "think like a lawyer". Additionally, in providing samples and directions for writing particular legal documents, they provide a good foundation for students to begin engaging in the second apprenticeship of technical expertise, though the conflation of good legal writing with good writing might be seen to underplay the extent to which the development of this expertise requires hard work with a unique writing approach. Further, the texts tend to underestimate the extent to which actual work within the community of practice will impact the development of technical writing competence.

Consistent with other accounts of legal education (Colby \& Sullivan, 2008), the first apprenticeship does seem to overshadow the other two within the texts. While first year texts make some reference to professional responsibility and client service, these references are minimal compared to the coverage of legal analysis and formulas for completing legal writing tasks. There seems to be room for attention to further linkages between personal values and interests, and how these factors work with others to shape the written products that ultimately represent the lawyer to the rest of the profession, and potentially to broader audiences. There is also, we argue, potential for the texts to adopt a more nuanced teacher-learner approach that recognizes the multi-faceted, recursive nature of the writing process.

The practitioner texts do address all of the three apprenticships: the intellectual aspects of writing, the skills aspects of writing (generally the purpose of each book), and either implicitly or explicitly, the identity aspects of writing. Lawyers are positioned as powerful in their control over writing through their the ability to confuse, to hide, to manipulate, to create clarity or to persuade. The identity aspects of these texts also includes a component of what we can only describe as the "self-loathing lawyer"; lawyer-authors who apparently find their 
community to be populated by a particular kind of malefactor. The texts may also promote the expert-novice relationship between author and new lawyer, based on the author's considerable experience. Students are encouraged to embrace the authors' views of effective legal writing, whatever it may be, as an antidote to a prevailing cultural of poor writing. The message to students and lawyers is that if they do not make the effort to write well that they are implicated in the community's indifference to good writing.

A number of interesting trends and contrasts emerge from the legal writing literature. There is a similar inattention to the writer's "voice" in both the first year and practitioner texts. Contrasts emerge, however, in relation to the representation of the legal writer. The range of descriptions found within practitioner texts is not replicated in the first year texts, which tend to quite consistently characterize the writer as a problem solver. Likewise, the negative rationales for poor legal writing found within the practitioner texts do not appear within the first year texts. These "disconnects" seem likely to create dissonance for young professionals in still-early stages of identity development. Neither set of texts explicitly recognizes the transitional issues in writing in school and writing at work.

\section{Educational Importance}

The findings within this study are important at a number of levels. At a very basic level, they clarify that texts do contain both spoken and unspoken messages with the potential to contribute to the manner in which professional identity is shaped. An awareness of these messages provides rich potential for discussion with students, and for students to engage with the identity question, including their acknowledgment of "self" as part of the writing process. The simple (yet express) articulation for students that they are entering into a new discourse community that is difficult, and at times, unsettling, may decrease the extent to which many of them feel alienated from law, particularly within their first year of study. Introducing students to "templates" for legal documents such as memoranda and advice letters after they have become acclimatized to legal analysis skills and legal language more generally may allow them to recognize the connection between personal and professional written identity before they are asked to become conversant with technical document format requirements. Further, recognizing legal writing as difficult work that does not necessarily flow naturally from one's 
prior writing experience can be empowering to the struggling legal writer. Identifying for upper year students the challenges of multifunctionality, complexity, and power issues that they can expect to face when transitioning into a work setting has the potential to better prepare them for their post-law school career. Students may need to understand how to manage the advice literature that minimizes or denigrates lawyers' commitment to a professional identity that includes effective writing.

Similarly, practitioner texts could assist new lawyers by acknowledging and surfacing the transition issues from writing in school to writing at work; in particular, by identifying the multiple power relations inherent in many documents. Such texts could provide support for the complexity of learning about document rhetoric - audience, purpose, and tone - across a range of document types. Given the nature and complexity of lawyers' writing, simplified frameworks are only marginally useful. Rather than relying primarily on the author's individual experience (while valuable), authors could investigate and provide evidence-informed rules and guidelines. Finally, authors could provide positive representation of lawyers as problem framers and problem solvers within an ethical approach to the administration of justice and the creation of relationships.

\section{Limits of the Research}

This study is limited by the sample size and selection. A different selection of first-year or practitioner texts may have yielded different representations of text as identity work. Given, however, the importance of the first year texts selected, the span of the findings would probably be consistent with the unexamined first year texts. For the practitioner texts, a different or larger sample would probably produce findings on the continuum described above: descriptions of legal writers that span from positive (legal writers face a daunting task) to negative (legal writers are inherently flawed) representations.

Further, it is unclear the extent to which individual texts are utilized within the community. It is possible that purchased works sit on bookshelves gathering dust. However, we argue that the discourse in and of itself represents a conversation within the professional community and that discourse analysis provides some descriptive insights to the nature of that conversation. 


\section{References}

Adams, K. A. (2004). A Manual of style for contract drafting.

Armstrong, S., \& Terrell, T. (2003). Thinking Like a Writer: A Lawyer's Guide to Effective Writing and Editing (Second ed.). New York: Practising Law Institute.

Atkinson, R. (1995). How the Butler Was Made to Do It: The Perverted Professionalism of" The Remains of the Day.". Yale Law Journal, 105(1).

Bebeau, M. J. (2008). Promoting Ethical Development and Professionalism: Insights from Educational Research in the Professions. U. St. Thomas LJ, 5, 366.

Colby, A., \& Sullivan, W. M. (2008). Formation of Professionalism and Purpose: Perspective from the Preparation for the Professions Program. U. St. Thomas $L J, 5,404$.

Dias, P., Freedman, A., Medway, P., \& Paré, A. (1999). Worlds Apart: Acting and Writing in Academic and Workplace Contexts. Mahwah: Lawrence Erlbaum Associates.

Elbow, P. (1998). Writing with Power:: Techniques for Mastering the Writing Process.

Elderkin, C., \& Doi, J. S. (1998). Behind and Beyond Boilerplate: Drafting Commercial Agreements. Toronto: Carswell.

Fairclough, N. (2003). Analysing discourse: textual analysis for social research: Psychology Press.

Farrow, T. C. W. (2008). Sustainable Professionalism. Osgoode Hall Law Journal, 46(1), 51.

Floyd, D. H. (2007). Lost Opportunity: Legal Education and the Development of Professional Identity. Hamline L. Rev., 30, 555.

Freedman, A., \& Adam, C. (1996). Learning to Write Professionally. Journal of Business and Technical Communication, 10(4), 395-427.

Garner, B. A. (2004). The Winning Brief (2nd ed.). Oxford: Oxford University Press.

Hamilton, N. (2008). Professionalism Clearly Defined," 18 No. Prof. Law., 4, 4 at 8.

Hamilton, N., \& Brabbit, L. M. (2007). Fostering Professionalism Through Mentoring. Journal of Legal Education, 57(1), 102.

Hutchinson, A. C. (1998). Legal ethics for a fragmented society: between professional and personal. International Journal of the Legal Profession, 5(2), 175-192.

Kamler, B., \& Thomson, P. (2006). Helping doctoral students write: Pedagogies for supervision: Psychology Press.

Kamler, B., \& Thomson, P. (2008). The failure of dissertation advice books: toward alternative pedagogies for doctoral writing. Educational Researcher, 37(8), 507.

Kennedy, D. (1987). Responsibility of Lawyers for the Justice of Their Causes, The. Texas Tech Law Review, 18, 1157.

Kierstead, S. M., \& Abner, E. (2010). A Preliminary Exploration of the Elements of Expert Performance in Legal Writing. Legal Writing Institute, 16, 363-408.

Law Societies, F. o. (2009). Task Force on the Canadian Common Law Degree. Ottawa: Federation of Law Societies.

LeMaistre, C., \& Paré, A. (2004). Learning in two communities: the challenge for universities and workplaces. Journal of Workplace Learning, 16(1/2), 44-52.

Litowitz, D. (1998). Legal Writing: its nature, limits and dangers. Mercer L. Rev., 49.

Longan, P. E. (2008). Teaching Professionalism. Mercer L. Rev., 60, 659.

Maclean, R. (2010). First-year law students' construction of professional identity through writing. Discourse Studies, 12(2), 177-194.

McCormack, B. (2008). Teaching Professionalism. Tennessee Law Review, 75.

Mersky, R. M. (2007). Legal Research Versus Legal Writing Within the Law School Curriculum. Law Libr. J., 99, 395. 
Nueuendorf, K. A. (2002). The content analysis guidebook. Thousand Oaks: Sage.

Phillips, N., \& Hardy, C. (2002). Discourse analysis: Investigating processes of social construction: Sage Publications, Inc.

Rideout, J. C. (2009). Voice, Self, and Persona in Legal Writing. Legal Writing: J. Legal Writing Inst., 15, 67.

Rideout, J. C., \& Ramsfield, J. J. (2010). The Legal Writing Institute: Celebrating 25 Years of Teaching \& Scholarship: A Symposium of the Mercer Law Review: A Special Focus on Legal Writing: Legal Writing: The View From Within. Mercer L. Rev., 61, 705-995.

Russell, C. K., \& Gregory, D. M. (2003). Evaluation of qualitative research studies. Evidence Based Nursing, 6(2), 36.

Schiess, W. (2003). Writing for the legal audience: Carolina Academic Pr.

Stark, S. D. (2000). Writing to win: the legal writer: Broadway Books, New York.

Sullivan, W. M., Colby, A., Wegner, J. W., Bond, L., \& Schulman, L. S. (2007). Educating Lawyers: Preparation for the Profession of Law. The Carnegie Foundation for the Advancement of Teaching: San Francisco, CA: Jossey-Bass.

Walker, D. S. (2008). Teaching and Learning Professionalism in the First Year with Some Thoughts on the Role of the Dean. U. Tol. L. Rev., 40, 421.

Winsor, D. (2001). Learning to Do Knowledge Work in Systems of Distributed Cognition. Journal of Business and Technical Communication, 15(1), 5-28.

Wydick, R. (1998). Plain English for Lawyers (4th ed.). Durham: Carolina Academic Press. 